\title{
Origins and quantification of nitrogen inputs into a coastal lagoon: Application to the Thau lagoon (France)
}

\author{
Marie-George Tournoud ${ }^{\text {a }}$, Sylvain Payraudeau ${ }^{\mathrm{a}}$, \\ Flavie Cernesson ${ }^{\mathrm{b}}$, Christian Salles ${ }^{\mathrm{a}}$ \\ ${ }^{\text {a } H y d r o S c i e n c e s ~ M o n t p e l l i e r ~(H S M, ~ J R U ~} 5569$ CNRS-IRD-Universités Montpellier 1 et 2), \\ Maison des Sciences de l'Eau, Université Montpellier 2, 34095 Montpellier cedex 5, France \\ ${ }^{\mathrm{b}}$ Territoires, Environnement, Télédétection et Information Spatiale (JRU CEMAGREF-CIRAD-ENGREF), \\ Maison de la Télédétection, 34093 Montpellier cedex 5, France
}

\section{Introduction}

Lagoon systems as interfaces between the continent and the sea are extremely vulnerable to the amount of pollutants they receive from various sources. In the case of nitrogen, important loads can lead to the progressive eutrophication of the lagoon (Kjerfve, 1994). The identification of the various sources of nitrogen and the evaluation of their respective contributions make it possible to define, on a hierarchical basis, which measure must be carried out for reducing the eutrophication phenomena (Ryding and Rast, 1992).

Various sources of nitrogen can be distinguished. First of all, the atmosphere, including dry and wet deposits, is a natural source of nitrogen for the lagoon. Even if it is not possible to act on this source, nitrogen loads brought by rainfall events must be evaluated, because it can account for a large fraction of total annual nitrogen contributions in natural areas (Bredemeier et al., 1998). Second, the sea, as it is connected to the lagoon, may be a source or a sink of nitrogen, depending on the level of the exchanges (Sfriso et al., 1994) that prove to be difficult to evaluate. Then urban stormwater drainage systems and sewage networks from cities or industries located along the lagoon shore constitute other sources of nitrogen for the lagoon. Nitrogen coming from these sources can have a strong impact on the lagoon because of the short distance between the source of pollution and the lagoon. The continental catchment area of the lagoon, via rivers or aquifers, constitutes the last, but prevalent, source of nitrogen for the lagoon (Rimmelin et al., 1998) and its contribution to the lagoon is not easy to estimate, because of its spatio-temporal variability and its hydrological complexity.

Each one of these sources has its' own temporal variability. On one hand, sea-lagoon exchanges and direct discharges due to human activities have a strong hourly variability but their seasonal variability is, in general, more limited. On the other hand, atmospheric and continental contributions are primarily event-based, especially in Mediterranean climatic context. The analysis of the various sources of pollution must thus be done at various time scales.

The analysis can be carried out on an annual scale. In LOICZ procedure (Talaue-McManus et al., 2003), mean annual water and mass budgets are calculated. These budgets are useful to weight the different com- 
ponents of the system and the priority actions to engage for controlling the eutrophication or degradation of the lagoon (Capodaglio et al., 1995). It can also be done on a succession of years for connecting the impact of socio-economic changes on the catchment area with accumulations of nitrogen in the lagoon (La Jeunesse, 2001). The analysis at rainfall-event scale is essential for Mediterranean lagoons, since a significant part of the annual amounts of pollutants is exported by rivers during rainfall events (Meybeck et al., 1992) and because sudden nitrogen inputs can cause local but important eutrophication damages in lagoons (Souchu et al., 1998; Harzallah and Chapelle, 2002).

This paper reports on the methods for evaluating nitrogen loads for the main sources at various contexts time scales, and presents an application on the Thau lagoon (Etang de Thau, France). The accuracy attached to the methods is discussed and, when possible, compared in the application. In particular, for estimating the river loads, a conceptual mathematical model, called POL (Payraudeau et al., 2002) is used and compared to the available data. The application is conducted for estimating annual and event-based nitrogen loads. To conclude, the main sources of nitrogen are classified, on a daily basis, for the Thau lagoon.

\section{Methodology review}

Nitrogen loads for a given source can be estimated by different methods according to the availability of data, the time step of analysis (annual or event-based) and the expected level of accuracy. This review of existing methods does not pretend to be exhaustive but to illustrate the diversity of the methods and their operational requirements. A longer development is devoted to river load calculations, since rivers are, most of the time, the major term in nitrogen budget of a coastal lagoon.

\subsection{Atmospheric contribution}

Nitrogen loads brought by the atmosphere constitute a significant part of total nitrogen loads in coastal environments (Burian et al., 2001; Jassby et al., 1994). Rainwater contains nitrogen in various forms, even if the dissolved ones are predominant. Dry deposits of dust and particles can also be associated with nitrogen. 
Total nitrogen concentrations in rainwater range between 0.5 and $2 \mathrm{mg} \mathrm{NL}^{-1}$ (Tabatabai, 1983) and these concentrations are all the more important when the study area is located close to large cities or industrial sites (Loye-Pilot et al., 1990). Atmospheric nitrogen loads can be estimated through direct in situ monitoring, extrapolation methods or physically based models.

The monitoring of the study area must involve rainfall gauging and sampling. Rainwater must be collected and analysed for each rainfall event for determining the local dynamics of total nitrogen atmospheric (dry and wet) deposits (Gao, 2002). The analytical protocol depends on the forms of nitrogen that are determined (Cape and Leith, 2002; Cornell et al., 2003). Uncertainty associated to the estimates depends essentially on the representativeness of the sampling sites and on the collector efficiency.

When local concentration monitoring are not available, in situ measurements in similar climatic and industrial context can be used as a first estimate and combined to local rainfall height measurements. For example, Spanish (Avila and Roda, 2002) or Greek (Dikaiakos et al., 1990) measurements are available and give a first evaluation of rainfall nitrogen contents around the Mediterranean Sea. These results compared well with those obtained in Corsica (France) by LoyePilot et al. (1990). But in every case, this extrapolation requires a great care to minimize the uncertainties.

The more sophisticated method would be to use a mathematical model. Models were developed by atmospheric physicists to simulate the spatial and temporal variability of the atmospheric deposits (Cocks et al., 1998; Burian et al., 2001; Alcamo et al., 2002). RAINS is an example (Barrett et al., 1995). These models need a lot of in situ measurement data to be calibrated. They are complex to use and nevertheless do not provide accurate estimates.

\subsection{The sea-lagoon exchanges}

Coastal lagoons are under marine influence. Water volumes exchanged between the lagoon and the sea are associated with dissolved and particulate elements. The impact in terms of nitrogen enrichment and impoverishment periods were shown in Mediterranean lagoons (Souchu et al., 1997). These phenomena depend both on the water volumes involved during the exchanges and on the concentrations of nitrogen in the two aquatic systems. Even if many empirical equations were proposed to evaluate pollutant exchanges between coastal lagoons and the sea (Yanagi, 2000), nitrogen concentrations measurements are always required both in the sea and in the lagoon, with a sufficient accuracy in space and time. Exchanged volumes also need to be evaluated.

Sea-lagoon exchanges are controlled by the dynamics of water levels and by the geometry of the channel. The variations of sea levels are due to tide and wind effects; evaporation, catchment inflows and wind control water levels in the lagoon. When sea and lagoon water levels are monitored, hydraulic formulae can be applied to evaluate exchanged volumes, given the section of the canal and its roughness (Chow, 1959). Hydrodynamic modelling can also be helpful for this evaluation (Lazure, 1992; Smith, 2001; Umgiesser and Zampato, 2001); these models allow to use refined time steps and their accuracy is good, but they require a lot of data and a reliable calibration/validation process. A global approach, based on water and salinity budget at lagoon scale, such as proposed by LOICZ methodology (Charpy-Roubaud et al., 1990; Talaue-McManus et al., 2003), can also be used. Despite of its simplicity, this method might only be used for annual estimates, moreover, its accuracy depends on the uncertainties affecting the other terms of the water budget.

\subsection{Domestic effluents}

Effluents of domestic sewage treatment works contain high loads of nitrogen (Calhoun et al., 2003; Lenzi et al., 2003), so this anthropogenic source of nitrogen could be harmful for the lagoon.

There are few operational models to simulate nitrogen loads at the outlet of a sewage treatment work, even if attempts were done (Clifforde et al., 1999). So nitrogen loads are always evaluated using in situ observations or empirical formulae. When flow and concentration are measured at a good frequency, standardized methods are proposed to calculate nitrogen annual loads from a sewage treatment work (OSPAR, 2000). These methods produce weighted averages of instantaneous nitrogen loads according to the sampling frequency. The uncertainty on the annual loads is related to the quality of the data. When no data are available, the estimate can be done using empirical methods (Valiela et al., 2002; Scheren et al., 2004), e.g. 
the product of the daily average nitrogen contribution per capita - that can be standardized according to the country (AIF, 1993) - by the theoretical yield of the sewage treatment work (Von Sperling and de Lemos Chernicharo, 2002). This estimate has a low accuracy but gives an order of magnitude for annual evalua- tion of nitrogen loads of a given sewage treatment work.

\subsection{Urban stormwater drainage effluents}

Runoff on urban impervious surfaces removes all the pollutants accumulated on these surfaces during the dry period. Collected by the stormwater drainage networks, these pollutants are directly flushed into the downstream aquatic systems. When the urban areas are located along the shore, most of the time the stormwater networks discharge directly into the lagoon.

Several modelling tools exist for the simulation of urban runoff during a rain event: SWMM (Metcalf et al., 1971), Hydroworks (Blanc et al., 1995), Canoe (INSA, SOGREAH, 1999). Water quality modules are associated to these models, which can even be coupled with models of atmospheric nitrogen deposits (Burian et al., 2001). Urban runoff models, even if they were developed for engineering purposes, require a lot of data (network geometry, topography, etc.). Moreover, concerning nitrogen loads, it was shown that the deviation between model results and in situ observations could be important (Brezonik and Stadelmann, 2002).

Many empirical formulae were set up, in various conditions. They link nitrogen yields to rainfall intensities and urban area characteristics: habitat density, street slopes, cleaning processes and types of impervious surfaces (e.g. Brezonik and Stadelmann, 2002; Bourrier, 1997). Even if the accuracy of these methods is not very high and difficult to evaluate when applied on ungauged urban areas, these formulae are often applied because of their easy-to-use.

\subsection{Groundwaters}

Nitrogen loads diffused by the aquifer into the lagoon, are due to the anthropogenic activities taking place on the continental basin: agriculture, urban area, domestic and industrial activities.
Groundwater monitoring consists in watertable measurements in piezometers, associated to water sampling and analysis. This monitoring is often done at regular time steps and allows the estimate of groundwater contamination level.

Nitrogen loads flowing through the aquifer can also be derived from these observed data, if the functioning of the aquifer is well known or with the help of a numerical model. But, the estimate of groundwater inputs to the lagoon (in term of flow, nitrogen ...) requires also defining the connections between the two aquatic systems. Direct measurements are possible using tracer experiments or in the case of existing springs along the coastline (as in the case of the Thau lagoon), however, most of the time such data are not available.

So groundwater nitrogen contribution to lagoons is often the less accurate term in the water or nitrogen budgets of the lagoon.

\subsection{Rivers}

Rivers that inflow into the lagoon may represent a large part of nitrogen budgets of lagoons or coastal areas (Nedwell et al., 2002). It is easy to control and monitor flow and water quality of the rivers, but loads remain difficult to estimate.

\subsubsection{Direct calculation}

In fact, if water levels are often continuously recorded and then converted into flow using rating curves, most of the time concentrations are only determined for instantaneous water samples taken at regular time steps: daily, weekly, monthly, etc. Several methods are proposed (Walling and Webb, 1985) for estimating annual or monthly river loads. Interpolation methods put forward hypotheses on the evolution of concentrations between two observed values. Extrapolation methods set empirical flow versus concentration relationships using observed data. Webb et al. (1997) showed that, whatever the method, the accuracy of the result is highly related to the sampling frequency. Moreover, for small basins and in Mediterranean context where nitrogen loads are mainly brought by the flash floods (Meybeck et al., 1992) very short sampling intervals must be set to estimate the river loads during floods.

To overcome this problem, some authors tried to set up statistical relationships between measured loads and 
other variables, such as basin properties (land use, area ...) or rainfall characteristics (Muller-Wohlfeil et al., 2001). But, the statistical adjustment is poor and lead to bad estimates of flood loads in Mediterranean context, as shown by Tournoud et al. (2003).

\subsubsection{Annual exportation models}

Annual export model is another approach for estimating river loads. Global export coefficients from agricultural areas were established in the main objective of lake management (Vollenweider, 1968; Jorgensen, 1980; US-EPA, 1980; Rast and Lee, 1983; Benneton, 1984). This approach was enhanced by Johnes (1996) and Worrall and Burt (2001) by using variable export coefficients. Payraudeau et al. (2001) use constant export coefficients in a GIS structured model to be able to characterize the spatial evolution of the loads along the river course.

These empirical models can be useful for estimating nitrogen loads in ungauged basins, but they only give an annual estimate and do not take into account interannual variations in precipitation and runoff that are an important feature of the Meditarranean climate.

\subsubsection{Water quality models}

Water quality models are attractive tools for evaluating nitrogen river loads at various time scales. These models combine hydrological and chemical equations and address different chemical species, including all nitrogen species. Chemical elements are transferred to the river through the surface or sub-surface flow, which are evaluated by the hydrological model. Chemical processes occurring in the soil and along the water paths are simulated. Among the large panel of existing models, some of them are often quoted: ANSWERS (Beasley et al., 1980) or AGNPS (Young et al., 1986) models are limited to small agricultural basins (a few square kilometres). HSPF (Donigian, 1984) addresses more specifically for assessing the effects of land-use change or reservoir operations; SWAT (Arnold et al., 1994) or AVGWLF (Evans et al., 2002) are integrated in GIS tools and developed for water management purposes in large agricultural basins.

These models involve numerous parameters and require large dataset for accurate simulation. But, the accuracy of model results is also related to the adequacy between the hydrological model and the hydrological behaviour of the basin. So, since existing water quality models were developed at field scale or for long-term simulation on a daily time step, they are not really adapted to Mediterranean catchments where floods are very fast and bring the main part of the annual river load.

\subsubsection{POL model}

POL model (Payraudeau et al., 2002) is an eventbased conceptual model designed to simulate nitrogen loads. The model was developed following two rules: parsimony in the number of parameters and adequacy to the behaviour of intermittent rivers. The model generates catchment responses to rainfall events, in terms of total nitrogen (TN) loads. It is based on a semi-distributed spatial delineation: the catchment is divided into hydrological units: sub-catchments and river reaches.

Two processes are considered in the model: (i) the production of $\mathrm{TN}$ loads by sub-catchments during the rainfall event and (ii) the transport of these TN loads along river reaches. Two simplifying assumptions are made in representing the complex processes of nitrogen delivery to the catchment outlet: (i) the rainfall triggers the $\mathrm{TN}$ mobilisation on hillslopes; (ii) $\mathrm{TN}$ loads are conservative along the river reaches during the event. Nitrogen point sources (such as sewage treatment plants) are defined as direct inputs in the river.

Each sub-catchment (Fig. 1a) is represented by a simple linear reservoir. At the beginning of the rainfall event, the reservoir content is a proportion $\alpha$ of the initial nitrogen stock NBV on the whole catchment ( $\alpha$ is the ratio of agricultural areas on the subcatchment to the whole catchment). The lag-time of the production reservoir is assumed to be the same for all sub-catchments. It is related to the rainfall event, through a filter function, which depends on a coefficient $F$. Each river reach (Fig. 1b) is represented by a series of linear reservoirs. The number of reservoirs depends on the length of the reach. The lag-time $T$ of the reservoirs is assumed to be the same for all reaches.

The model was run on a data set of 15 floods. The hydrological and water quality data were collected in three intermittent rivers in the South of France. An unbiased criterion was used to check the model for performance and quality. It compares observed and simulated load and event duration of each flood 

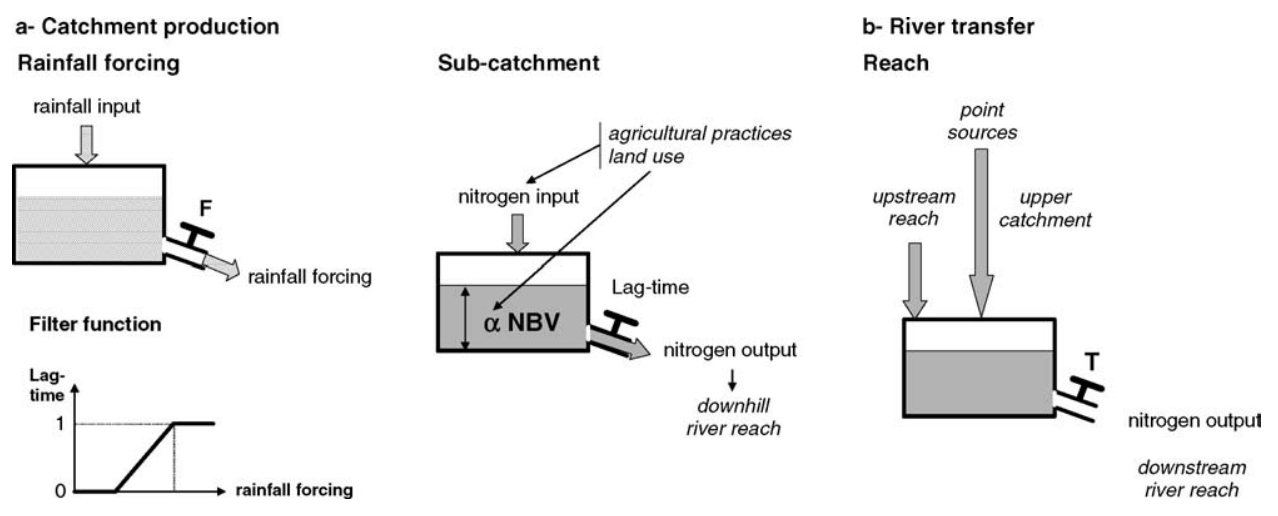

as following:

\section{Criterion}

$$
\begin{gathered}
=1-\frac{\text { | observed load }- \text { simulated load } \mid}{\text { observed load }} \\
-\frac{\text { observed duration }- \text { simulated duration } \mid}{\text { observed duration }} .
\end{gathered}
$$

The calibration analysis showed that (i) the filter coefficient $F$ can be set regardless of the catchment and the flood; (ii) the river lag-time $T$ is statistically related to the duration of the rainfall event and the total rainfall amount in the 30 days before the event; (iii) the initial stock NBV can be related to crops and agricultural practices (Payraudeau, 2002). Assuming these pre-defined parameter values, the model was re-run on the 15 floods

\section{Application site and data}

\subsection{Thau lagoon}

The Thau lagoon is located along the French Mediterranean coast (Fig. 2). It covers an area of $75 \mathrm{~km}^{2}$ with an average depth of $4 \mathrm{~m}$. The lagoon is separated from the sea by a sandy lido that links the city of Sète $(40,200$ inhabitants) to Marseillan beach (3000 inhabitants in the summer time). The catchment area is sparsely populated: about 35,600 inhabitants are

\begin{tabular}{|c|c|c|c|c|c|}
\hline Event & Obs_load $(\mathrm{kg} \mathrm{N})$ & Obs_duration (h) & Sim load $(\mathrm{kg} \mathrm{N})$ & Sim_duration (h) & Criterion \\
\hline 1 & $111 \pm 55$ & $34 \pm 4$ & 400 & 63 & -2.45 \\
\hline 2 & $4107 \pm 2053$ & $77 \pm 4$ & 7669 & 93 & -0.07 \\
\hline 3 & $3304 \pm 1652$ & $120 \pm 4$ & 2949 & 92 & 0.66 \\
\hline 4 & $69 \pm 34$ & $17 \pm 4$ & 26 & 15 & 0.23 \\
\hline 5 & $295 \pm 147$ & $69 \pm 4$ & 1379 & 68 & -2.69 \\
\hline 6 & $16422 \pm 8211$ & $200 \pm 4$ & 10970 & 105 & 0.20 \\
\hline 7 & $3127 \pm 1653$ & $79 \pm 4$ & 1163 & 84 & 0.31 \\
\hline 8 & $3341 \pm 1670$ & $168 \pm 4$ & 7530 & 219 & -0.56 \\
\hline 9 & $11966 \pm 5983$ & $245 \pm 4$ & 10640 & 119 & 0.38 \\
\hline 10 & $335 \pm 167$ & $22 \pm 4$ & 3171 & 19 & 0.80 \\
\hline 11 & $337 \pm 168$ & $19 \pm 4$ & 760 & 27 & -0.67 \\
\hline 12 & $733 \pm 366$ & $48 \pm 4$ & 1513 & 51 & -0.13 \\
\hline 13 & $656 \pm 328$ & $33 \pm 4$ & 322 & 27 & 0.32 \\
\hline 14 & $3674 \pm 1837$ & $142 \pm 4$ & 2706 & 97 & 0.42 \\
\hline$\underline{15}$ & $502 \pm 252$ & $33 \pm 4$ & 936 & 30 & 0.03 \\
\hline
\end{tabular}

Table 1

POL model: performances with pre-defined parameters 


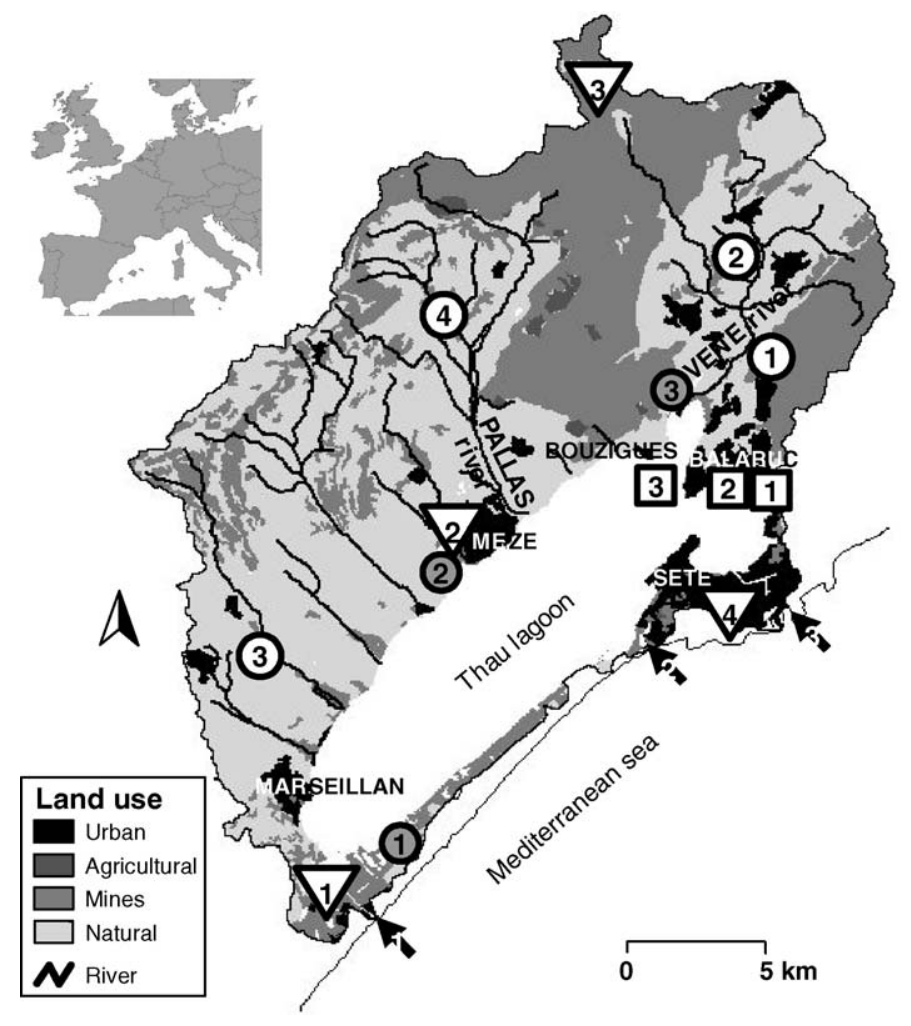

Rain gauges

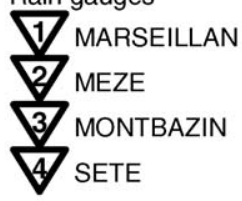

WWTP (direct)

(1) MARSEILLAN

(2) MEZE

(3) POUSSAN

WWTP (others)

(1) GIGEAN

(2) MONTBAZIN

(3) PINET-POMEROLS

(4) Villeveyrac

\section{Karstic springs \\ 1 AMBRESSAC \\ 2 CAUVY \\ 3 VISE}

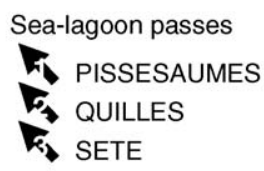

Fig. 2. The Thau lagoon and its environment.

spread in small villages. Even if tourism is an important economical activity around the lagoon (the population doubles in summer), the main activity remains shellfish farming. All over the year the lagoon is highly productive, but dystrophic crisis often happen during the summer period due to the excess of nutrients in the lagoon (Souchu et al., 1998).

Small villages are settled on the shoreline: Balarucles-Bains, Bouzigues, Marseillan, and Mèze. Their stormwater drainage systems output directly in the lagoon, draining up to $6.8 \mathrm{~km}^{2}$ of urban areas. The city of Sète is also partly drained directly into the lagoon $\left(7.3 \mathrm{~km}^{2}\right)$. Three sewage treatment works discharge directly into the lagoon (Marseillan, Mèze and Poussan); they use extensive processes with stabilization ponds. There are some industries around the lagoon, located close to Balaruc: they locally impact on nitrogen concentrations in groundwater.

The lagoon catchment (area of $269 \mathrm{~km}^{2}$ ) consists of karstified limestone and marls from the Miocene. The basin is drained by small intermittent rivers that show a long dry period between May and September and flush flash floods during the wet season. The Vène River $\left(67 \mathrm{~km}^{2}\right)$ is the most important one and the only one fed by karstic springs; the Pallas River drains an area of $52 \mathrm{~km}^{2}$; the other rivers have smaller catchment areas. The main part of the Thau basin (54\% of the total area) is devoted to agricultural activities: mainly vineyards (25\% of basin area), plus orchards and market gardening. The impervious zones cover $9 \%$ of the basin and include urban centres as well as industrial and commercial zones. Nitrogen inputs in the basin are mainly due to the provision of fertilizers on the fields, in particular for market gardening. The industrial activities are linked to agriculture: wineries (private or cooperative) and poultry farms are the main ones. Cooperative wineries and poultry farms have their own treatment devices or are connected to a sewage treatment work. Private wineries have small outputs and do not seem to have an impact on the lagoon in terms of nitrogen 
inputs. The rivers receive the effluents of four sewage treatment works (Pinet-Pomerols, Villeveyrac, Montbazin, Gigean) that use stabilization pond processes.

The western part of the basin is lying on a karstic aquifer that shows several outfalls into the lagoon:

a sub-marine spring (Vise spring) and two shoreline springs (Cauvy and Ambressac). It was shown that the western porous aquifer does not impact on the lagoon or on the intermittent rivers.

The lagoon is connected to the sea by three passes: two shallow passes (Pissesaumes and Quilles) through the sandy lido are blocked; the deep canal crossing the city of Sète contributes to the main part of the sealagoon exchanges.

\subsection{Nitrogen load calculation}

Nitrogen loads from the different sources were estimated for the Thau lagoon for the period stretching from September 1998 to August 1999 (hydrological year 1998-1999) and for one significant flood event in November 1999.
Table 2

Rainfall event (11-12 November 1999) at Montbazin station

\begin{tabular}{lc} 
Rain event beginning & 11 December 1999, 21 h and $15 \mathrm{~min}$ \\
$\begin{array}{l}\text { Maximum intensity over } \\
5 \mathrm{~min}\left(\mathrm{~mm} \mathrm{~h}^{-1}\right)\end{array}$ & 26.4 \\
& \\
Total rainfall (mm) & 167.2 \\
Rainfall event duration (h) & 73 \\
\hline
\end{tabular}

The Montbazin rain gauge was used to evaluate rainfall amounts and intensities for the reference period and event. The hydrological year (September 1998 to August 1999) was a dry year with a total rainfall amount of $517 \mathrm{~mm}$ (local annual average value: $750 \mathrm{~mm}$ ). The storm event of November 1999 (Table 2) had lasted about 3 days with high peak intensity and a total amount of $167 \mathrm{~mm}$ within $72 \mathrm{~h}$.

Table 3 summarizes the available data for each source of nitrogen during the reference period and event. The data were collected during research projects, funded by local authorities and the French Ministry of environment (Contrat pour l'Etang de Thau, 1997;

Table 3

Thau lagoon - synthesis of the available data and methods of evaluation

\begin{tabular}{|c|c|c|c|c|c|}
\hline $\mathrm{N}$ source & Measurement & Location & Time interval & Frequency & References \\
\hline \multirow[t]{2}{*}{ Rainfall } & Rainfall height & Montbazin & Since July 1994 & Continuous & $\begin{array}{l}\text { Contrat pour l'Etang } \\
\text { de Thau (1997) }\end{array}$ \\
\hline & Concentration & & In 2003-2004 & Some events, bulk & $\begin{array}{l}\text { Salles (unpublished } \\
\text { data) }\end{array}$ \\
\hline \multirow[t]{2}{*}{ Sea-lagoon exchange } & Discharge & Sète Canal & $\begin{array}{l}\text { January } \\
\text { 1994-December } \\
1996\end{array}$ & Hourly & $\begin{array}{l}\text { Contrat pour l'Etang } \\
\text { de Thau (1997) }\end{array}$ \\
\hline & Concentration & & & $\begin{array}{l}\text { Hourly samples } \\
\text { during five tidal } \\
\text { events }\end{array}$ & \\
\hline Domestic effluent & $\begin{array}{l}\text { Discharge } \\
\text { Concentration }\end{array}$ & Marseillan and Mèze & Since 2001 & Almost monthly & Local authorities \\
\hline Urban drainage & None & - & - & - & - \\
\hline \multirow[t]{2}{*}{ Groundwater } & Discharge & Vise, Cauvy, Ambressac & $\begin{array}{l}\text { January 1998-May } \\
2000\end{array}$ & $\begin{array}{l}\text { Monthly till August } \\
\text { 1999, then in } \\
\text { November } 1999 \text { and } \\
\text { May } 2000\end{array}$ & $\begin{array}{l}\text { Contrat pour l'Etang } \\
\text { de Thau (1997) }\end{array}$ \\
\hline & Concentration & & & & Tournoud et al. (2004) \\
\hline \multirow[t]{2}{*}{ Rivers } & Discharge & Vène River & $\begin{array}{l}\text { Since September } \\
1994\end{array}$ & Continuous & $\begin{array}{l}\text { Contrat pour l'Etang } \\
\text { de Thau (1997) }\end{array}$ \\
\hline & Concentration & Pallas River & & $\begin{array}{l}\text { Monthly, plus hourly } \\
\text { samples for some } \\
\text { floods }\end{array}$ & Tournoud et al. (2004) \\
\hline
\end{tabular}


Table 4

Sea-lagoon exchanges: available data

\begin{tabular}{|c|c|c|c|c|c|}
\hline Campaign & $\# 1$ & $\# 2$ & $\# 3$ & \#4 & $\# 5$ \\
\hline \multicolumn{6}{|c|}{$\mathrm{NO}_{3}$ concentrations $^{\mathrm{a}}\left(\mathrm{g} \mathrm{NL}^{-1}\right)$} \\
\hline Average & 28 & 40 & 142 & 42 & 57 \\
\hline $1 / 2 \max -\min$ & 5 & 17 & 15 & 18 & 12 \\
\hline
\end{tabular}

Tidal cycle from lagoon to sea

$\begin{array}{lrrrrr}\text { Average } & 32 & 30 & 124 & 19 & 49 \\ 1 / 2 \text { max-min } & 12 & 11 & 9 & 21 & 7\end{array}$

$\mathrm{NH}_{4}$ concentrations ${ }^{\mathrm{a}}\left(\mathrm{g} \mathrm{NL}^{-1}\right)$

Tidal cycle from sea to lagoon

$\begin{array}{lrrrrr}\text { Average } & 8 & 26 & 14 & 7 & 21 \\ 1 / 2 \text { max-min } & 6 & 6 & 8 & 8 & 4 \\ \begin{array}{l}\text { idal cycle from lagoon to sea } \\ \text { Average }\end{array} \quad 5 & 25 & 8 & 14 & 9 \\ 1 / 2 \text { max-min } & 3 & 20 & 5 & 3 & 3\end{array}$

${ }^{\text {a }}$ Calculated from hourly observed concentrations during the cycle.

Tournoud et al., 2004). GIS data were also available for the lagoon catchment: digital elevation model (from BD Alti ${ }^{\circledR}$ IGN), land-use map (from Sagot, 1999), geological map (from BRGM), river network (from BD Carto ${ }^{\circledR}$ IGN), locations of urban drainage outlets, sewage treatment works (STW) and industries (from BD Carto ${ }^{\circledR}$ IGN and Hérault Province). Agricultural practices were studied by Dauriac (2000). The data are gathered in Tables 3-8. For each source of nitrogen, we retained the method that best fits the available data.

\subsubsection{Atmospheric input}

Nitrogen loads from the atmosphere were estimated by combining of continuous rainfall heights with
Table 6

Characteristics of urban areas

\begin{tabular}{llll}
\hline & Inhabitants & $\begin{array}{c}\text { Urban area } \\
2 \\
(\mathrm{~km})\end{array}$ & $\begin{array}{c}\text { Population density } \\
2\end{array}$ \\
\hline City of Sète & 26361 & 7.3 & 3596 \\
Other viltages & 20274 & 6.8 & 2999
\end{tabular}

Table 7

$\underline{\text { Karstic springs: observed nitrogen loads }}$

\begin{tabular}{|c|c|c|c|c|c|c|c|c|c|}
\hline \multirow[t]{2}{*}{$\left(\mathrm{kg} \mathrm{N}\right.$ day $\left.^{-1}\right)$} & \multicolumn{3}{|c|}{ VISE } & \multicolumn{3}{|c|}{ CAUVY } & \multicolumn{3}{|c|}{ AMBRESSAC } \\
\hline & NT & $\mathrm{NO}$ & ${ }_{3} \mathrm{~N}$ & $4 \mathrm{NT}$ & $\mathrm{NO}$ & $3 \underline{N H}$ & ${ }_{4} \mathrm{NT}$ & $\mathrm{NO}_{3}$ & $\mathrm{NH}$ \\
\hline Average $^{a}$ & 13 & 9 & 0 & 18 & 15 & 0 & 98 & 60 & 7 \\
\hline Half min-max interva & 112 & 6 & 0 & 36 & 30 & 0 & 129 & 94 & 51 \\
\hline High water period & 22 & 14 & 0 & 72 & 62 & 0 & 460 & 283 & 30 \\
\hline \multicolumn{10}{|l|}{ Low water period } \\
\hline In summer & 4 & 4 & 0 & 3 & 3 & 0 & 17 & 16 & 0 \\
\hline In winter & 10 & 8 & 0 & 17 & 14 & 0 & 40 & 24 & 2 \\
\hline
\end{tabular}

Calculated from monthly data (1998-1999), January-December: 10, 8, 0, 17, 14, 0, 40, 24, 2, 67, 46, 2.

bulk nitrogen concentrations measured during rainfall events.

No concentration data were available during the reference period. So, concentrations of nitrates and ammonium in the atmospheric deposits were estimated on the data collected between September 2003 and April 2004. Bulk rainfall concentrations ranged between 0.2 and $0.6 \mathrm{mg} \mathrm{N} \mathrm{L}^{-1}$ for nitrates and between 0.1 and $0.7 \mathrm{mg} \mathrm{N} \mathrm{L}^{-1}$ for ammonium (Salles, unpublished data). The loads were calculated using the same concentration value for nitrates and ammonium $\left(0.3 \mathrm{mg} \mathrm{N} \mathrm{L}^{-1}\right)$. The uncertainty is set to be the half of the min-max interval.

Table 5

Characteristics of sewage treatment works

\begin{tabular}{lcccc}
\hline Sewage treatment works & Population (nb permanent inhab.) & Connection ratio (\%) & Treatment yield (\%) & Output loads (kg N day $\left.^{-1}\right)$ \\
\hline Directly flowing into the lagoon & & & 37 \\
\hline Marseillan & 7587 & 84 & 39 & $21 \pm 18$ \\
Mèze & 3507 & 88 & 78 & $\mathrm{a}$ \\
Poussan & 1815 & 88 & & $\mathrm{a}$ \\
Inside the watershed & & & 18 & $\mathrm{a}$ \\
Gigean & 3552 & 99 & 78 & $\mathrm{a}$ \\
Montbazin & 2214 & 94 & 64 & $\mathrm{a}$ \\
Pinet-Pomerols & 2686 & 89 & 72 & \\
Villeveyrac & 1974 & 89 & & \\
\hline
\end{tabular}


Table 8

Vène River flood (November 1999): flood characteristics and nitrogen loads

\begin{tabular}{lc} 
Flood event beginning & $\begin{array}{c}12 \text { December } \\
5 \mathrm{~h} \text { and } 55 \mathrm{~min}\end{array}$ \\
Base flow $\left(\mathrm{m}^{3} \mathrm{~s}^{-1}\right)$ & 0.266 \\
Peak flow $\left(\mathrm{m}^{3} \mathrm{~s}^{-1}\right)$ & 29 \\
Total flood volume $\left(10^{3} \mathrm{~m}^{3}\right)$ & 7220000 \\
Flood duration $(\mathrm{h})$ & 156 \\
Total nitrogen load & \\
Observed $(\mathrm{kg} \mathrm{N})$ & 9770 \\
$\quad$ POL model $(\mathrm{kg} \mathrm{N})$ & 10700 \\
Peak nitrogen $\operatorname{load}$ & \\
Pbserved $\left(\mathrm{kg} \mathrm{Nh}^{-1}\right)_{1}$ & 226.7 \\
\hline
\end{tabular}

\subsubsection{Sea-lagoon exchanges}

Nitrogen exchanges between the Thau lagoon and the sea were only considered through the Sète canal and restricted to nitrates and ammonium. Sea-lagoon exchanges were monitored in 1995 and 1996; hourly flow data and five sampling campaigns were available during this period. The mean value of the net daily volume exchanged through the canal was esti- mated, over the 2 years, to about $250,000 \mathrm{~m}^{3}$ seaward: in average, the lagoon outflows into the sea about $5,300,000 \mathrm{~m}^{3}$ but inflows about $5,050,000 \mathrm{~m}^{3}$ per day. Nitrogen concentrations showed low variations within a tidal cycle, but large differences between the five observed cycles (Table 4). Regarding the limited number of data, no attempt to link observed loads to climatic conditions were done. So, arbitrary choices were made for sea-lagoon exchange calculations.

For each campaign, daily net nitrogen loads exchanged through the canal were evaluated as the difference between in-load and out-load: out-load was defined as the product of daily average volume by average nitrogen concentration observed during seaward tidal cycles (in-loads referred to lagoonward tidal cycles). The minimum and maximum net daily loads were obtained for \#1 and \#3 campaigns, respectively. During the \#1 campaign (20 June 1995), the net daily nitrogen load was evaluated to $-14 \mathrm{~kg} \mathrm{~N}$ the negative value indicating that the in-load $(182 \mathrm{~kg} \mathrm{~N})$ is lower than the out-load $(196 \mathrm{~kg} \mathrm{~N})$. The \#3 campaign (9 December 1995) took place just after a large storm event $(57.2 \mathrm{~mm}$ of rainfall recorded in one day at Montbazin station). The net daily nitrogen load was esti- mated to $88 \mathrm{~kg} \mathrm{~N}$, with an in-load of $788 \mathrm{~kg} \mathrm{~N}$ per day ( $717 \mathrm{~kg} \mathrm{~N}$ in nitrates and $71 \mathrm{~kg} \mathrm{~N}$ in ammonium) and an out-load of $700 \mathrm{~kg} \mathrm{~N}$ per day $(657 \mathrm{~kg} \mathrm{~N}$ in nitrates and $42 \mathrm{~kg} \mathrm{~N}$ in ammonium). The mean net daily value was defined as the average between the two campaigns. The uncertainty was set to half of the min-max interval, it reached $100 \%$.

\subsubsection{Domestic effluents}

No data were available during the reference period and event. Table 5 shows the present characteristics of sewage treatment works. Process yields and connection rates were giyen bv the local water authorities. Annual and daily loads were estimated using present measurements, when available (Marseillan and Mèze). For the other sewage treatment works, average contribution per capita was combined to process yield: an empirical value of $15 \mathrm{~g} \mathrm{~N}$ per day and per inhabitant (AIF, 1993) was used here. Uncertainty was given by the observed range of variability.

\subsubsection{Urban stormwater effluents}

No in situ data are available for evaluating stormwater effluents around the lagoon. Nitrogen loads in urban runoff (NLUR in $\mathrm{kg} \mathrm{km}^{-2}$ ) were evaluated using the following formula (Bourrier, 1997):

$\mathrm{NLUR}=4.725 \times 10^{-2}(0.14+0.1$

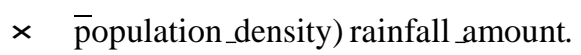

Urban zones around the lagoon were mapped to evaluate the impervious areas. The population data were issued from the last population inventory. Data are gathered in Table 6.

\subsubsection{Groundwaters}

The three karstic springs flowing into the Thau lagoon were monitored in 1998-1999, on a monthly basis. Monthly nitrogen loads were evaluated by combining estimated flow values with measured nitrogen concentrations. Table 7 presents a summary of observed nitrogen loads. The two shoreline springs showed highly variable loads, Ambressac spring was subject to high contamination from local industries. Since the monitoring period corresponds to a dry year, no attempt was done to link observed data to hydrological conditions. So, the annual groundwater load was estimated with the average value. The event load was 


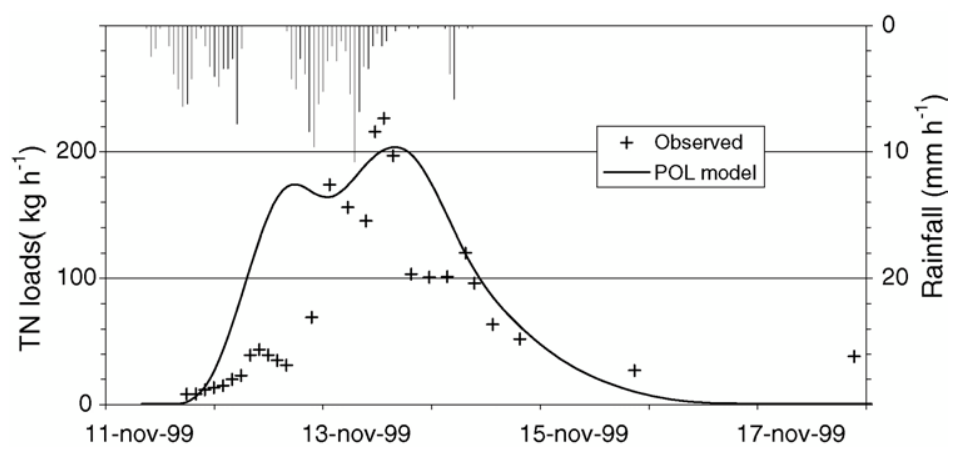

Fig. 3. Vène River - total nitrogen loads (11-18 November 1999)—POL model simulation.

estimated from high flow daily value. Uncertainty was set to half of the max-min interval; it reached $100 \%$.

\subsubsection{Rivers}

Flow data are only available for Vène and Pallas Rivers during the reference period. Monthly sampling was carried out during the same period. During November 1999, a significant flood event occurred: samples were collected and analysed for nitrogen contents in the Vène River. Since only two rivers (among 10) were monitored, river loads were calculated using POL model.

The accuracy of the model was first tested on November 1999 flood event. Table 8 and Fig. 3 present the characteristics of the observed flood and the model results. The peak load produced by the model compares well to the observed values. The deviation is less than $12 \%$ for the total load. The temporal dynamic is also
Table 9

Pallas River (year 1998-1999): annual nitrogen load

\begin{tabular}{lll}
$\begin{array}{l}\text { POL model } \\
\text { (tonnes N) }\end{array}$ & $\begin{array}{l}\text { Annual export } \\
\text { model }^{\mathrm{a}} \text { (tonnes N) }\end{array}$ & $\begin{array}{l}\text { Direct calculation } \\
\text { (tonnes N) }\end{array}$ \\
\hline 15 & & 8 \\
& & \\
&
\end{tabular}

well reproduced by the model. One-year simulation was then carried out on the year 1998-1999 (Fig. 4); the results compared well to the monthly observed loads.

The uncertainty of the model estimates was checked on an annual run on the Pallas River (1998-1999). Annual nitrogen loads (Table 9) compare well to the estimate given by an annual export model (Payraudeau et al., 2001) and to a direct calculation done from available monthly data (Payraudeau et al., 2001). As already mentioned, the hydrological year 1998-1999 was dry: the Pallas River was only flowing during a

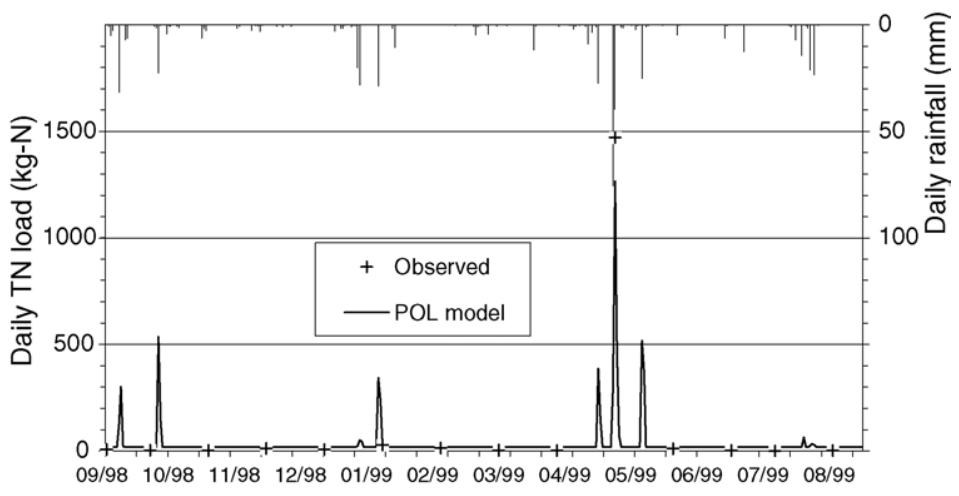

Fig. 4. Vène River — total nitrogen loads (September 1998-August 1999)—POL model simulation. 
few weeks. So, the export model overestimates the nitrogen load during this dry year since it calculates an inter-annual average value. Considering the difference between direct calculation and model result, the uncertainty on POL model was set to $\pm 50 \%$.

POL model was then run on each river draining the Thau lagoon catchment during the reference period and the flood event.

\section{Results and conclusion}

\subsection{Nitrogen load input into the Thau lagoon}

Table 10 gathers estimates of total nitrogen inputs to the Thau lagoon for the different sources; when possible the estimates in term of nitrates and ammonium are also given.

\subsubsection{Annual loads}

The total amount of nitrogen brought to the Thau lagoon by external sources can be estimated to about 190 tonnes with an uncertainty of at least $83 \%$.

Rivers and aquifer represent more than two-third. Concerning the other sources, it is remarkable that for the year 1998-1999, rain and domestic effluents have the same weight while urban runoff seems to be negligible. Even if the calculation refers to a very dry year the most important nitrogen sources for the Thau lagoon is related to rainfall that trigger urban runoff, river discharge and aquifer flow.

These figures do not take into account the sealagoon exchanges. Available data on the Sète canal are too poor to allow an accurate estimate of the nitrogen loads involved in the sea-lagoon exchanges. The annual load depends on the methodology used to extrapolate the observed values. The different tests have shown a so large range of result values that it is impossible to conclude if there is enrichment or impoverishment of the Thau lagoon through the Sète canal during the year. If uncertainties on the other sources of nitrogen are reduced, it will then be possible to estimate this term using a budget method (like LOICZ for example).

\subsubsection{Event loads}

An intense storm event occurred in November 1999. The total rainfall height during the event represented one-third of the annual rainfall recorded the previous hydrological year (Table 2). As recorded at the Vène outlet, the flood event lasted 7 days. The nitrogen loads were evaluated over the same duration. Sea-lagoon exchanges were not evaluated here.

More than 40 tonnes of nitrogen was brought to the lagoon in 7 days, that is to say a quarter of the annual amount calculated for one dry year (1998-1999). Assuming the perfect mixing of the lagoon and combining nitrogen input to lagoon volume, the nitrogen concentrations in the lagoon will increase by $0.2 \mathrm{mg} \mathrm{N} \mathrm{L}^{-1}$. Rivers and rain brought more than $85 \%$ of the total amount. The aquifer, since its response is much slower and more attenuated than the river, seems to have a lower impact.

\subsubsection{Daily loads}

Daily loads were calculated on average, during the flood event and during dry day. Comparing an average day to a rainy day (Table 11), the same conclusion can

Table 10

Nitrogen inputs in the Thau lagoon: during 1 year; during one storm event

\begin{tabular}{|c|c|c|c|c|c|c|c|}
\hline \multirow[t]{2}{*}{ (tonnes $\mathrm{N}$ ) } & \multicolumn{3}{|c|}{$\begin{array}{l}\text { One year, September } \\
\text { 1998-August } 1999\end{array}$} & \multicolumn{3}{|c|}{$\begin{array}{l}\text { During one flood event, } 11-18 \\
\text { November } 1999\end{array}$} & \multirow[t]{2}{*}{ Uncertainties (\%) } \\
\hline & $\mathrm{TN}$ & $\mathrm{NO}_{3}$ & $\mathrm{NH}_{4}$ & $\mathrm{TN}$ & $\mathrm{NO}_{3}$ & $\mathrm{NH}_{4}$ & \\
\hline Rain & 23 & 12 & 12 & 7.5 & 3.7 & 3.7 & \pm 100 \\
\hline Rivers & 80 & - & - & 30.9 & - & - & \pm 50 \\
\hline Groundwater & 58 & 38 & 6 & 3.6 & 2.3 & 0.2 & \pm 100 \\
\hline Urban areas & 2 & - & & 0.6 & - & - & $?$ \\
\hline WWTP & 25 & - & & 0.7 & - & - & \pm 70 \\
\hline Total & 188 & - & - & 43.3 & - & - & \\
\hline Sea exchanges & 13 & 6 & 7 & - & & & \pm 125 \\
\hline
\end{tabular}

-: No data available. 
Table 11

Nitrogen inputs in the Thau lagoon: during 1 day in different hydrological conditions

\begin{tabular}{lcccc}
\hline TN $\left(\mathrm{kg} \mathrm{N}\right.$ day $\left.^{-1}\right)$ & Daily average & Storm event & Dry day, in summer & Dry day, in winter \\
\hline Rain & 63 & 1071 & 0 & 0 \\
Rivers & 219 & 4414 & 43 & 71 \\
Groundwater & 159 & 514 & 24 & 67 \\
Urban areas & 5 & 86 & 0 & 0 \\
WWTP & 68 & 100 & 110 & 60 \\
Total & 515 & 6186 & 177 & 242 \\
Sea exchanges & 36 & - & - & - \\
\hline
\end{tabular}

-: No data available.

be drawn: nitrogen sources associated to rainfall (rain, rivers, aquifer and urban runoff) prevails over domestic effluents.

But, in summer, when rivers and aquifer are almost dry, sewage treatment works become the major input of nitrogen for the lagoon, all the most because of the increase in population. The continuous input of treated water contributes to the accumulation of nitrogen close to discharge location and may lead to local dystrophic crisis during the summer period (Souchu et al., 1998).

\subsection{Conclusion}

Estimating nitrogen inputs into a lagoon is not an easy task, even when a large set of data is available as it is for the Thau lagoon. It was impossible to reach our initial goal: comparing methods. Moreover, uncertainties are difficult to determine.

For the Thau lagoon, the budget of external nitrogen sources shows the great importance of rain-driven sources compared to direct domestic effluents. Since river and groundwater loads are predominant (except in the summer period), reliable estimation tools have to be developed. POL model that was built in this aim gives already good results for small Mediterranean rivers. Yet it must be enhanced, because it does not take into account nitrogen species.

The large uncertainties attached to sea-lagoon exchanges must be reduced: the solution could be to use hydrodynamic models. Urban area nitrogen loads to the lagoon need to be better known, but seems to be negligible in the budget. At last, direct rainfall was demonstrated to be a significant input of nitrogen for the lagoon and must be taken into account in the nitrogen budget for a lagoon.

\section{Acknowledgments}

The authors want to thank Prof. B. Picot (Université de Montpellier 1), P. Souchu (IFREMER), N. Dorfliger (BRGM) for the availability of the data and C. Rodier (CNRS) for the database management. This study was driven in the framework of two research projects: Programme National d'Environnement Côtier Lagunes Méditerranéennes and DITTY project (EU EESD Project EVK3-CT-2002-00084) (European Union, 2002).

\section{References}

AIF, 1993. Recherche et quantification des paramètres caractéristiques de l'équivalent-habitant: étude bibliographique. Etude Inter Agences, No. 23, Paris, France, p. 41.

Alcamo, J., Mayerhofer, P., Guardans, R., van Harmelen, T., van Minnen, J., Onigkeit, J., Posch, M., de Vries, B., 2002. An integrated assessment of regional air pollution and climate change in Europe: findings of the AIR-CLIM Project. Environ. Sci. Policy 5 (4), 257-272.

Arnold, J.G., Williams, J.R., Srinivasan, R., King, K.W., Griggs, R.H., 1994. SWAT (Soil and Water Assessment Tool) User's Manual. USDA, Agricultural Research Service, Grassland, Soil and Water Research Laboratory, Temple, USA.

Avila, A., Roda, F., 2002. Assessing decadal changes in rainwater alkalinity at a rural Mediterranean site in the Montseny Mountains (NE Spain). Atmos. Environ. 36, 2881-2890.

Barrett, K., Seland, O., Foss, A., Sandnes, H., Styve, H., Tarrason, L., 1995. European transboundary acidifying air pollution: ten years calculated fields and budgets to the end of the first sulphur protocol. EMEP/MSC-W Report 1/95, Oslo, Norway.

Beasley, D.B., Beasley, Huggins, L.F., Monke, E.J., 1980. ANSWERS: a model for watershed planning. Trans. ASAE 23 (4), 938-944.

Benneton, J.C., 1984. Eutrophisation des plans d'eau: inventaire des principales sources nutritives azotées et phosphorées - etude bibliographique. CEMAGREF, Paris. 
Blanc, D., Kellagher, R., Phan, L., Price, R., 1995. FLUPOLMOSQITO, models, simulations, critical analysis and development. Water Sci. Technol. 32 (1), 185-192.

Bourrier, R., 1997. Evaluation des flux polluants. Les réseaux d'assainissement: calculs, applications, perspectives. Lavoisier Tec \& Doc, Paris, France, pp. 195-247.

Bredemeier, M., Blank, K., Xu, Y.J., Tietema, A., Boxman, A.W., Emmett, B., Moldan, F., Gundersen, P., Schleppi, P., Wright, R.F., 1998. Input-output budgets at the NITREX sites. Ecol. Manage. $101(1-3), 57-64$.

Brezonik, P.L., Stadelmann, T.H., 2002. Analysis and predictive models of stormwater runoff volumes, loads, and pollutant concentrations from watersheds in the Twin Cities metropolitan area, Minnesota, USA. Water Res. 36, 1743-1757.

Burian, S.J., Streit, G.E., McPherson, T.N., Brown, M.J., Turin, H.J., 2001. Modeling the atmospheric deposition and stormwa- ter washoff of nitrogen compounds. Environ. Model. Software 16 (5), 467-479.

Calhoun, D.L., Frick, E.A., Buell, G.R., 2003. Effects of urban development on nutrient loads and streamflow, upper Chattahoochee river basin, Georgia, 1976-2001. In: Proceedings of the Georgia Water Resources Conference, Athens, USA, April 2003, pp. 1-5.

Cape, N.J., Leith, I.D., 2002. The contribution of dry deposited ammonia and sulphur dioxide to the composition of precipitation from continuously open gauges. Atmos. Environ. 36 (39-40), 5983-5992.

Capodaglio, A.G., Baschieri, P., Bendoricchio, G., 1995. Diffuse pollution from urban areas in the Venice Mainland: estimation, and possible intervention scenaria. In: Proceedings of the Conference on Pollution of Large Cities, Venice, February 22-25, 1995, pp. 27-36.

Charpy-Roubaud, C.J., Charpy, L., Cremoux, J.L., 1990. Nutrient budget of the lagoonal waters in an open South Pacific atoll (Tikehau Tuamotu French Polynesia). Mar. Biol. 107, 67-73.

Chow, V.T., 1959. Open Channel Hydraulics. McGraw-Hill, Inc., USA.

Clifforde, I.T., Tomicic, B., Mark, O., 1999. Integrated wastewater management: a European vision for the future. In: Proceedings of the Eighth International Conference on Urban Storm Drainage, Sydney, Australia, USA, August 30-September 2, 1999, pp. 168-179, Available in http://www.dhisoftware.com/book/content1.htm.

Cocks, A.T., Rodgers, I.R., Skeffington, R.A., Webb, A.H., 1998. The limitations of integrated assessment modelling in developing air pollution control policies. Environ. Poll. 102 (1-1), 635-639.

Contrat pour l'Etang de Thau, 1997. Suivi des apports du bassin versant de l'étang de Thau et des échanges avec la mer par les canaux de Sète. Contrat pour l'étang de Thau, volet A: études et recherches, rapport final. Agence de l'Eau Rhô neMéditerranée-Corse, Conseil Général 34. DIREn LanguedocRoussillon, France, p. 175.

Cornell, S.E., Jickells, T.D., Cape, J.N., Rowland, A.P., Duce, R.A., 2003. Organic nitrogen deposition on land and coastal environments: a review of methods and data. Atmos. Environ. 37 (16), 2173-2191.

Dauriac, F., 2000. Analyse de l'utilisation de l'espace pour la quantification des flux d'azote. Application au bassin versant de l'étang de l'Or (Hérault). DEA (M.Sc. Thesis). Engref, Montpellier, p. 100.

Dikaiakos, J.G., Tsitouris, C.G., Siskos, P.A., Melissos, D.A., Nastos, P., 1990. Rainwater composition in Athens, Greece. Atmos. Environ. Part B: Urban Atmos. 24 (1), 171-176.

Donigian, A.S., 1984. Application guide for Hydrological Simulation Program-Fortran (HSPF). US Environmental Protection Agency, EPA-600/3-84-065, Athens, Georgia, USA, p. 177.

European Union, 2002. Development of an Information Technology Tool for the Management of European Southern Lagoons under the influence of river-basin runoff, DITTY project. 2002. Programme Energy, Environment and Sustainable Development, European Commission. Equipe Coordinatrice ECOLAG: Université Montpellier II, Unité Mixte de Recherche CNRS-UMII, 5119, p. 93 (Ecosystèmes Lagunaires).

Evans, B.M., Lehning, D.W., Corradini, K.J., Petersen, G.W., Nizeyimana, E., Hamlett, J.M., Robillard, P.D., Day, R.L., 2002. A comprehensive GIS-based modeling approach for predicting nutrient loads in watersheds. J. Spat. Hydrol. 2 (2), 2-18.

Gao, Y., 2002. Atmospheric nitrogen deposition to Barnegat Bay. Atmos. Environ. 36 (38), 5783-5794.

Harzallah, A., Chapelle, A., 2002. Contribution of climat variability to occurrences of anoxic crises 'malaïgues' in the Thau lagoon (southern France). Oceanol. Acta 25, 79-86.

INSA, SOGREAH, 1999. CANOE-User Manual. INSA Lyon, Villeurbanne, France.

Jassby, A.D., Reuter, J.E., Axler, R.P., 1994. Atmospheric deposition of nitrogen and phosphorus in the annual load of Lake Tahoe (California-Nevada). Water Resour. Res. 30 (7), 2207-2216.

Johnes, P.J., 1996. Evaluation and management of the impact of land use change on the nitrogen and phosphorus load delivered to surface waters; the export coefficient modelling approach. J. Hydrol. $183,323-349$.

Jorgensen, S.E., 1980. Lake Management. Pergamon, Oxford.

Kjerfve, B., 1994. Coastal Lagoon Processes. Elsevier Science Publishers, Amsterdam, The Netherlands, p. 577.

La Jeunesse, I., 2001. Etude intégrée dynamique du phosphore dans le système bassin versant-Lagune de Thau. Thèse. Université d'Orléans, France, p. 290.

Lazure, P., 1992. Etude de la dynamique de l'étang de Thau par modèle numérique tridimentionnel. Vie milieu 42 (2), 137-145.

Lenzi, M., Palmieri, R., Salvatore, P., 2003. Restoration of the eutrophic Orbetello lagoon (Tyrrhenian Sea, Italy): water quality management. Marine Poll. Bull. 46 (12), 1540-1548.

Loye-Pilot, M.D., Martin, J.M., Morelli, J., 1990. Atmospheric input of inorganic nitrogen to the Western Mediterranean. Biogeochemistry 9, 117-134.

Metcalf, E., University of Florida and Water Resources Engineers, 1971. Storm water management model, vol. I-final report. Water Pollution Control Research Series 11024 DOC 07/71. Environmental Protection Agency, Washington, DC, USA.

Meybeck, M., Bouloubassi, I., Wen, H.W., Hubert, P., Pasco, A., Ragu, A., Toma, A., 1992. Etablissement des flux polluants. Rapport interagences, Laboratoire de Géologie appliquée. Naturalia Biologia, p. 500.

Muller-Wohlfeil, D.I., Kronvang, B., Larsen, S.E., Ovesen, N.B., Wendland, F., 2001. Establishment of a harmonized tool for 
calculating river discharge and nitrogen loads from unmonitored areas in Denmark. Phys. Chem. Earth (B) 26 (7-8), 617622.

Nedwell, D.B., Dong, L.F., Sage, A., Underwood, G.J.C., 2002. Variations of the nutrients loads to the mainland UK. Estuar- ies: correlation with catchment areas, urbanization and coastal eutrophication. Estuar. Coast. Shelf Sci. 54, 951-970.

OSPAR, 2000. Guideline 4: Quantification and Reporting of Nitrogen and Phosphorus Discharges from Sewage Treatment Works and Sewerage. OSPAR Commission, London, UK, pp. 1-4, Available in http://www.euroharp.org/rl/guidelines/.

Payraudeau, S., 2002. Modélisation distribuée des flux d'azote sur des petits bassins versants méditerranéens. Ph.D. Thesis. Engref, Montpellier, p. 436.

Payraudeau, S., Tournoud, M.G., Cernesson, F., 2002. An adapted modelling approach for the nitrogen load management on a catchment scale. In: Hassanizadeh, S.M., Scotting, R.J., Gray, W.G., Pinder, G.E. (Eds.), Computational Methods in Water Resources, Development in Water Science, vol. 47, No. 2. Elsevier, Amsterdam, The Netherlands, pp. 1741-1748.

Payraudeau, S., Tournoud, M.G., Cernesson, F., Picot, B., 2001. Annual nutrients export modelling by analysis of landuse a,d topographic information: case of a small Mediterranean catchment. Water Sci. Technol. 44 (2-3), 321-327.

Rast, W., Lee, G.F., 1983. Nutrient loading estimates for lakes. J. Environ. Eng. 109, 502-517.

Rimmelin, P., Dumon, J.C., Maneux, E., Goncalves, A., 1998. Study of annual and seasonal dissolved inorganic nitrogen inputs into the Arcachon lagoon, Atlantic coast (France). Estuar. Coast. Shelf Sci. 47 (5), 649-659.

Ryding, S.O., Rast, W., 1992. Le control e de l'eutrophisation des lacs et des reservoirs. In: Sciences de l'environnement 9. Masson, p. 294.

Sagot, O., 1999. Conception et réalisation d'une couche d'informations géoréférencées sur l'occupation du sol des zones humides et de leurs bassins versants du littoral de la région Languedoc-Roussillon. Université Louis Pasteur, Strasbourg, France, p. 62.

Scheren, P.A.G.M., Kroeze, C., Janssen, F.J.J.G., Hordijk, L., Ptasinski, K.J., 2004. Integrated water pollution assessment of the Ebrié lagoon, Ivory Coast, West Africa. J. Mar. Syst. 44 (1-2), 1-17.

Sfriso, A., Marcomini, A., Pavoni, B., 1994. Annual nutrient exchanges between the central lagoon of Venice and the northern Adriatic Sea. Sci. Total Environ. 156 (1), 77-92.

Smith, N.P., 2001. Seasonal-scale transport patterns in a multi-inlet coastal lagoon. Estuar. Coast. Shelf Sci. 52 (1), 15-28.

Souchu, P., Abadie, E., Vercelli, C., Buestel, D., Sauvagnargues, J.C., 1998. La crise anoxique du bassin de Thau de l'été 1997: Bilan du phénomène et perspectives. IFREMER, p. 33.

Souchu, P., Gasc, A., Cahet, G., Vaquer, A., Collos, Y., DeslousPaoli, J.M., 1997. Biogeochemical composition of Mediter- ranean waters outside Thau Lagoon. Estuar. Coast. Shelf Sci. 44, 275-284.

Tabatabai, M.A., 1983. Atmospheric deposition of nutriments and pesticides. In: Shaller, F.W., Bailey, G.W. (Eds.), Agricultural Management and Water Quality. Iowa State University Press, Ames, IA, USA, pp. 92-108.

Talaue-McManus, L., Smith, S.V., Buddemeier, R.W., 2003. Biophysical and socio-economic assessments of the coastal zone: the LOICZ approach. Ocean Coast. Manage. 46 (3-4), 323-333.

Tournoud, M.G., Payraudeau S., Dorfliger, N., Picot, B., Souchu, P., Cernesson, F., Luck, J.M., Rodier, C., 2004. Dynamique et qualité des apports superficiels et souterrains aux lagunes du LanguedocRoussillon. Contrat de Plan-Etat-Région Environnement, Région Languedoc-Roussillon, rapport final, p. 297.

Tournoud, M.G., Salles, C., Picot, B., Payraudeau, S., Rodier, C, 2003. Sediment and nutrient flood loads in three small Mediterranean catchments. Proc. Hydrology of the Mediterranean and Semiarid Regions, IAHS Publ. 278, Montpellier, April 2003, pp. 484-491.

Umgiesser, G., Zampato, L., 2001. Hydrodynamic and salinity modeling of the Venice channel network with coupled 1-D-2-D mathematical models. Ecol. Model. 138 (1-3), 75-85.

US-EPA, 1980. Modelling phosphorus loading and lake response under uncertainty: a manual and compilation of export coefficients. Rep. EPA44015-80-011. US Environmental Protection Agency, Report CN-69.

Valiela, I., Bowen, J.L., Kroeger, K.D., 2002. Assessment of models for estimation of land-derived nitrogen loads to shallow estuaries. Appl. Geochem. 17 (7), 935-953.

Vollenweider, R.A., 1968. Scientific fundamentals of stream and lake eutrophication, with particular reference to nitrogen and phosphorus. OECD Tech. Rep. DAF/DST/88, Paris.

Von Sperling, M., de Lemos Chernicharo, C.A., 2002. Urban wastewater treatment technologies and the implementation of discharge standards in developing countries. Urban Water 4, 105-114.

Walling, D.E., Webb, B.W., 1985. Estimating the discharge of contaminants to coastal waters by rivers: some cautionary comments. Marine Poll. Bull. 16, 488-492.

Webb, B.W., Phillips, J.M., Walling, D.E., Littlewood, I.G., Wattas, C.D., Leeks, G.J.L., 1997. Load estimation methodologies for British rivers and thei relevance to the LOIS RACS(R) programme. Sci. Total Environ. 194/195, 379-389.

Worrall, F., Burt, T.P., 2001. Inter-annual controls on nitrate export from an agricultural catchment-how much land-use change is safe? J. Hydrol. 243 (3-4), 228-241.

Yanagi, T., 2000. Coastal Oceanography. Kluwer Publishers, Dordrecht, The Netherlands, p. 162.

Young, R.A., Onstad, C.A., Bosch, D.D., Anderson, W.P., 1986. Agricultural Nonpoint Source Pollution Model: A Watershed Analysis Tool. Agricultural Research Service, US Departement of Agricultural, Moris, MN, USA. 